\title{
INTERLEUKIN-1 FAMILY: FROM GENES TO HUMAN DISEASE
}

\author{
Beáta Laurincová
}

Department of Immunology, Medical Faculty of Palacký University, I. P. Pavlova 6, 77520 Olomouc, Czech Republic

Received July 15, 2000

Key words: Interleukin-1 / Interleukin-1 receptor antagonist / Gene polymorphism

Interleukin-1 (IL-1) is one of the most potent proinflammatory cytokines involved both in physiological immune responses and in the development of various immunopathological disorders. The members of IL- 1 family form a complex system with tight regulatory mechanisms and clarifying their role in disease remains in the centre of research interests. This review article except of summarising recent findings about IL-1 family members focuses on associations of IL-1 gene complex polymorphisms with human diseases.

\section{INTRODUCTION}

The immune response is regulated by cytokine network, in which the synergy and antagonism of particular cytokines must be finely tuned to reach the right outcome. Both inadequate and too strong immune reaction can impair the organism and result in inflammatory and autoimmune diseases, respectively. According to their function, cytokines can be divided into groups of proinflammatory or antiinflammatory mediators. One of the key roles in cytokine network is played by the members of the interleukin-1 family. Mediators, belonging to this group, are the proinflammatory agonists IL-1 $\alpha$, IL-1 $\beta$ and their naturally occuring inhibitor interleukin-1 receptor antagonist (IL-1Ra). Recently, novel members of IL-1 superfamily, interleukin-18 ${ }^{1}$, FIL1 $\delta$, FIL1 $\varepsilon$, FIL1 $\zeta$, and FIL1 $\eta^{2}$ have been described. The members of the IL-1 family show conserved amino acid motifs and share similar tertiary structure. Conserved exonintron pattern suggests that they evolved from a common ancestor.

IL-1 and IL-1Ra specifically bind to surface receptor molecules or to their soluble forms. There are two receptors binding IL-1. Interaction with the type I receptor (IL-1RI) leads to signal transduction, while type II receptor (IL-1RII) acts as a "decoy" receptor sequestering IL-1 without inducing signalling. An indispensable participant of the IL-1 signalling complex is the IL-1 receptor accessory protein (IL-1RAcP). Novel IL-1 receptor-like genes, the T1/ST2 (IL-1RL1), IL-1 receptor related protein (IL-1Rrp) and IL-1 receptor related protein 2 (IL-1RL2) have been identified during the human genome sequencing project ${ }^{3}$.

The genes encoding members of IL-1 family are clustered on the long arm of the chromosome 2, except of IL-18 and IL-1RAcP, which are located on the chromosomes 11 and 3, respectively ${ }^{3,4,5}$. IL-1 family genes are polymorphic and their alleles are in linkage disequilibrium ${ }^{6}$.

\section{CHARACTERISTICS OF IL-1 FAMILY MEMBERS}

\section{IL-1 $\alpha$ and IL-1 $\beta$}

Gene. Genes for IL-1 $\alpha$ (IL1A), IL-1 $\beta$ (IL1B) and IL-1Ra (IL1RN) are located on 2q14-217. They map to a common restriction fragment of approximately $430 \mathrm{~kb}$, where they are distributed in following intervals: IL1A between +0 and $+35 \mathrm{~kb}$, IL1B between +70 and $+110 \mathrm{~kb}$, IL1RN between +330 and $+430 \mathrm{~kb}^{4}$. The promoter region of IL-1A does not contain TATA box, a typical motif for inducible genes, which is present in the IL-1B.

Regulation of expression. IL- $1 \alpha$ is constitutively expressed in human keratinocytes, other cells synthesise and release IL- $1 \alpha$ under stimulation ${ }^{8,9}$. IL- $1 \beta$ is produced by wide range of cells, particularly of monocytemacrophage lineage. There is a large number of microbial or non-microbial inducers of IL-1, such as lipopolysacharide (LPS), immune complexes, stress factors, neuroactive substances, cytokines ${ }^{10,11}$. Constitutive levels of IL-1 $\beta$ mRNA have been detected in many organs and tissues. However, a dissociation between the transcription and translation is characteristic for IL-1 $\beta^{12}$. Transcription is induced by various stimulants without translation. The untranslated mRNA is degraded unless an additional signal is provided ${ }^{10}$. One possible explanation for this phenomenon is regulation of mRNA half-life through AURE (Adenylate Uridylate Rich Element). IL-1 $\beta$ mRNA contains an AURE typical for mRNAs, which require tight control of protein synthe$\operatorname{sis}^{11}$.

Synthesis and processing. Both IL- $1 \alpha$ and IL-1 $\beta$ are synthesised as $31-\mathrm{kDa}$ precursors without conventional signal peptide, characteristic for secreted proteins ${ }^{10}$. Mature $17-\mathrm{kDa}$ forms of IL- $1 \alpha$ and IL- $1 \beta$ have a trefoillike tri-dimensional structure composed of 12 to 14 folds of $\beta$-pleated sheet. The protein precursors are translated on polysomes in connection with cytoskeletal microtubules, remain in cytosol and do not accumulate in any organelle. Either proIL- $1 \alpha$ or proIL-1 $\beta$ are 
myristoylated on lysine residues during the process of posttranscriptional modification ${ }^{13}$. Myristoylated proIL- $1 \alpha$ is translocated to the cell surface or can be cleaved to a mature form by membrane-associated calcium-dependent cysteine proteases called calpains ${ }^{14}$. After cleavage IL $-1 \alpha$ is released to extracellular space. IL- $1 \alpha$ is fully active both as precursor or mature protein, whereas IL-1 $\beta$ is active only in its mature form. In keratinocytes and partially in tissue macrophages, the predominant form of IL-1 $\beta$ after stimulation is intracellular proIL-1 $\beta^{15}$. The active mature $17-\mathrm{kDa}$ IL-1 $\beta$ arises from cleavage of proIL-1 $\beta$ at aspartic acid at position 116 by interleukin- $1 \beta$ converting enzyme (ICE, recently called caspase- 1$)^{16}$. In mononuclear phagocytes, the ICE cleavage of proIL-1 $\beta$ also at $\mathrm{Asp}^{28}$ was demonstrated. Processing of proIL-1 $\beta$ is not indispensable for IL-1 $\beta$ export into extracellular compartment. IL-1 $\beta$ is secreted from intact LPS-stimulated monocytes as 3-, 17-, 28- and 31-kDa forms ${ }^{15}$. The released $31-\mathrm{kDa}$ form is different from cytosolic $31-\mathrm{kDa}$ proIL-1 $\beta$, what could be explained by conformational changes during the process of secretion. Apart from ICE, proIL-1 $\beta$ can be cleaved by other proteolytic enzymes, such as trypsin, chymotrypsin, bacterial enzymes, leukocyte elastase, granzyme A, and matrix metalloproteinases (MMPs) ${ }^{17}$. MMPs including stromelysin-1, gelatinases $\mathrm{A}$ and $\mathrm{B}$, are induced by IL-1 $\beta$ at sites of acute and chronic inflammation, where they are able both to activate and catabolise IL-1 $\beta$.

Function. The biologic effects of IL-1 have been described in detail in previous reviews ${ }^{10}$. IL- $1 \alpha$ acts as an intracellular autocrine messenger, which regulates the normal cell differentiation, especially in epithelial and ectodermal cells. ProIL- $1 \alpha \mathrm{NH}_{2}$ terminal region contains a nuclear localisation sequence and has been demonstrated to bind in cell nuclei ${ }^{18}$. Elevated levels of IL-1 $\alpha$ were proposed to play role in senescence and growth inhibition of fibroblasts and endothelial cells. The critical role of IL-1 $\beta$, but not of IL- $1 \alpha$, in febrile and neuro-immune-endocrine responses was described in IL-1 $\alpha-/-$, IL1 $\beta-/-$ knockout (KO) mice ${ }^{19}$. IL-1 $\beta$ is crucial for the induction of fever and acute-phase response during local tissue damage, whereas in systemic inflammation it only contributes to inflammatory reaction $^{20,21}$. Similar to IL-1 $\beta$-/- mice, IL-1RI-deficient animals have a reduced acute phase response to local injury. Data obtained in studies with IL-1RI-deficient mice suggest that both IL- $1 \alpha$ and IL- $1 \beta$ are important in response to tissue damage and infection, but are not required for normal development and homeostasis ${ }^{22}$. In the response to inflammatory and infectious challenges IL-1 modulates the process of extravasation and localisation of leukocytes at inflammatory sites, which involves leukocyte adhesion and passage through endothelial linings ${ }^{10}$. IL-1 participates in recruiting and activating neutrophils and macrophages, producing vascular dilatation with alteration of endothelial integrity. It also induces production of acute phase reactants, wide range of cytokines, adhesive molecules, prostanoids, free-radical generating enzymes etc. Further, IL-1 enhances pro- liferation of fibroblasts, smooth muscle cells or mesiangial cells ${ }^{10}$.

\section{IL-1Ra}

IL-1 receptor antagonist has currently three known isoforms: glycosylated soluble IL-1Ra (sIL-1Ra) and two intracellular non-glycosylated forms (icIL-1Ra I and icIL-1Ra II).

Gene. sIL-1Ra and icIL-1Ra I are generated from the same gene by use of alternative first exon ${ }^{23}$. The expression of sIL-1Ra and icIL-1Ra I is regulated by two distinct promoters located upstream to each alternative first exon with different transcriptional regulatory elements. The regulation of icIL-1Ra expression is realised in cell type-specific manner ${ }^{24}$.

Structure. IL-1Ra has a $\beta$-trefoil crystallographic structure, which is similar to those of IL-125. The characteristics of particular isoforms are listed in Table 1. sIL-1Ra is translated as a $17-\mathrm{kDa}$ protein with 177 amino acids containing a 25 -amino acid leader sequence ${ }^{10}$. After processing, which includes cleavage of the leader sequence and glycosylation, it is secreted by classical endoplasmatic reticulum - Golgi - secretory vesicles pathway into the extracellular environment. Intracellular forms of IL-1Ra are not glycosylated, do not possess leader sequence and remain in intracellular compartment. icIL-1Ra II is derived by alternative translation initiation from either sIL-1Ra mRNA and icIL-1Ra I mRNA $^{26}$. Two different icIL-1Ra II have been described. mRNA coding for a larger $25-\mathrm{kDa}$ form of icIL-1Ra was found in human polymorphonuclear cells, which differed from icIL-1Ra I in additional 21 amino acid sequence present within the $\mathrm{NH}_{2}$-terminal portion ${ }^{27}$. This additional stretch was encoded by an extra exon located $2 \mathrm{~kb}$ downstream between the first and second exon of icIL-1Ra I. Even if this mRNA is expressed in several cell types, the corresponding $25-\mathrm{kDa}$ protein has not been found yet ${ }^{28}$.

Table 1. Characteristics of IL-1Ra isoforms.

\begin{tabular}{|l|c|c|l|}
\hline isoform & $\begin{array}{c}\text { molecular } \\
\text { weight }\end{array}$ & $\begin{array}{c}\text { number of } \\
\text { amino acids }\end{array}$ & \multicolumn{1}{|c|}{ Producing cell types } \\
\hline sIL-1Ra & $22-25 \mathrm{kDa}$ & 152 & $\begin{array}{l}\text { monocytes, macrophages, neutrophils, fibroblasts, } \\
\text { hepatocytes, microglia }\end{array}$ \\
\hline icIL-1Ra I & $18 \mathrm{kDa}$ & 159 & $\begin{array}{l}\text { keratinocytes, epithelial cells, monocytes, } \\
\text { macrophages }\end{array}$ \\
\hline icIL-1Ra II & $16 \mathrm{kDa}$ & 143 & $\begin{array}{l}\text { fibroblasts, keratinocytes, epithelial cells, } \\
\text { neutrophils, myelomonocytes, hepatoma HepG2 cells }\end{array}$ \\
\hline
\end{tabular}

Abbreviations: sIL-1Ra, soluble IL-1 receptor antagonist; icIL-1Ra I, intracellular IL-1 receptor antagonist type I; icIL-1Ra II, intracellular IL-1 receptor antagonist type II.

Regulation of production and function. IL-1Ra production is induced by variety of mediators including cytokines, viral products, and acute phase proteins. The most potent inducers of IL-1Ra in vitro are LPS, IL-4, adherent $\mathrm{IgG}$ and GM-CSF${ }^{28}$. Differential production of distinct IL-1Ra isoforms by LPS-stimulated peripheral mononuclear blood cells (PMBC) and neutrophils 
was demonstrated ${ }^{29}$. sIL-1Ra is an inducible gene in most cells, icIL-1Ra is expressed constitutively in keratinocytes and intestinal epithelial cells ${ }^{10}$. The early transcription and translation of sIL-1Ra both in polymorphonuclear leukocytes and in PBMC may regulate the biological activity of IL-1 in extracellular space. The transcription and translation of icIL-1Ra I in PBMC is delayed, and possibly it has an intracellular regulatory function. In transduced human ovarian carcinoma cells icIL-1Ra I does not inhibit initial IL-1 $\beta$ responses, but attenuates IL-1 $\beta$-inducible early gene expression by alteration of mRNA stability ${ }^{30}$. The existence of intracellular regulatory loops modulating the activities of intracellular IL-1 family members has been suggested ${ }^{31}$. In cultured dermal fibroblasts from patients with systemic sclerosis elevated intracellular proIL-1 $\alpha$ up-regulates the levels of icIL-1Ra. icIL-1Ra II is produced by neutrophils and PBMC as an inducible cytoplasmic protein, which follows the kinetics of SIL-1 $\mathrm{Ra}^{29}$. The physiological inhibition of IL-1 by IL-1Ra appears to protect the organism from exaggerated reaction to infection, but brings along the risk of impairing the host's ability to eliminate the infection. The IL-1Ra $\mathrm{KO}$ mice are more susceptible to lethal endotoxemia but are less susceptible to infection with intracellular agent Listeria monocytogenes $^{32}$. The absence of IL-1Ra in KO mice resulted also in decreased body mass compared with wild-type controls suggesting that IL-1Ra is not required for normal development, but it is necessary for maintaining normal body mass by mechanism antagonising the IL-1-mediated appetite suppression and catabolism $^{32}$.

\section{IL-1 receptors}

Six members of the interleukin-1 receptor family are currently known ${ }^{3}$. The family contains: type I IL-1 receptor (IL-1RI), type II IL-1 receptor (IL-1RII), IL-1 receptor accesory protein (IL-1RAcP), T1/ST2 (IL-1 RL1), IL-1 receptor related protein (IL-1Rrp) and IL-1 receptor related protein 2 (IL-1RL2). The extracellular portion of these receptors is composed of three IgG-like domains which share significant homology to each other ${ }^{3,10}$. Five of six IL-1 receptor-like genes map to $2 \mathrm{q} 12$, while the IL-1RAcP to $3 \mathrm{q} 28$.

$I L-1$ receptor type $I$. IL-1RI is a transmembrane monomeric $80-\mathrm{kDa}$ glycoprotein, constitutively expressed on $\mathrm{T}$ lymphocytes, fibroblasts, chondrocytes, endothelial cells, smooth muscle cells and other cell types ${ }^{25}$. Signal transduction via IL-1RI requires recruitment of IL-1RAcP, which is an essential signal transducing component in functional IL-1R complex ${ }^{33}$.

IL-1 receptor accessory protein. IL-1RAcP is a 570amino acid protein, which shares limited homology to both IL-1 receptors. The conformational changes induced in ligand-receptor complex by tight binding of the IL- 1 agonists to the second binding site in the domain 3 of the receptor (which is not present in IL-1Ra), allow a secondary interaction of this complex with IL-1 $\mathrm{RAcP}^{28}$. IL-1RAcP increases the affinity of the IL-1RI for all IL-1 agonists, but differentially affects binding of IL- $1 \alpha$ and IL-1 $\beta^{33}$. IL-1Ra binds to extracellular portion of IL-1RI without triggering the association of IL-1 RAcP.

IL-1 receptor type II. IL-1RII is a $68-\mathrm{kDa}$ glycoprotein with shortened intra-cytoplasmatic domain in comparison with IL-1RI ${ }^{34}$. It is expressed on the same cells as the IL-1RI with the exception of endothelial cells ${ }^{25}$. IL-1RII is unable of signal transducing and competes with IL-1RI for IL-1. IL-1RII does not act only as a scavenger of IL-1 but also of IL-1RAcP. IL-1RII alters IL-1 activity by subtracting IL-1RAcP from IL-1RI signalling complex ${ }^{35}$. Thus the IL-1RI / IL-1RII ratio on the cell membrane is an important factor regulating IL-1 cell responsiveness. Expression of IL-1RII is modified by diverse external signals. Particularly anti-inflammatory agents (IL-4, IL-13, dexamethason) can up-regulate IL-1RII surface expression in human macrophages and neutrophils ${ }^{36}$.

Soluble forms of receptors. The soluble forms of IL-1 RI and II are derived by proteolytic cleavage of extracellular domains of membrane receptors. They can be detected in the serum or urine of healthy subjects, but also in different inflammatory body fluids ${ }^{37}$. The levels of sIL-1RII are higher than sIL-1RI both in normal and pathologic situations. The affinity of soluble receptors for IL-1 and IL-1Ra is different from membrane-bound receptors. For sIL-1RI, the rank is IL-1Ra $>\mathrm{IL}-1 \alpha>\mathrm{IL}-1 \beta$, for sIL-1RII IL-1 $\beta>$ IL-1 $\alpha>$ IL1-Ra ${ }^{10,25}$.

Signal transduction. The binding of IL-1 to IL-1RI allows the association of IL-1RAcP, thus forming a highaffinity complex for IL-1 ${ }^{35}$. The ligand-induced association of two transmembrane molecules results in the interaction of their cytoplasmic domains necessary for the recruitment of the IL-1 receptor associated protein kinases (IRAK, IRAK-2, IRAK-M) ${ }^{38,39,40}$. IRAK then dissociate from the IL-1R complex and associate with TNF receptor-associated factor-6 (TRAF-6). The members of the IRAK family are indispensable elements for LPS signal transduction ${ }^{40}$. Events including multiple and sequential phosphorylations and dephosphorylations of distinct kinases (e.g. MAP kinases) result in activation of proteins participating in translation and translocation of transcriptional factors (particularly $\mathrm{NF \kappa B}$ and AP-1) to the nucleus. A member of Rho family of GTPases - RhoA appears to constitutively interact with the cytoplasmic domain of IL-1RI as a component of the IL-1 signalling complex. The activation of RhoA leads to IL-1-stimulated Rho-dependent cytoskeleton reorganisation, which is necessary for persistent cell activation in chronic inflammatory disease ${ }^{41}$.

\section{IL-18}

IL-18, previously called IFN $\gamma$-inducing factor, has been classified to IL-1 family on the basis of its structural homology. Contrarily to other IL-1 family members, the gene of IL-18 maps to 11q22.2-q22.35. IL-18 is constitutively expressed in many haematopoetic cell lines of myelomonocytic origin, murine splenocytes, osteo- 
blasts, mouse keratinocytes, rat adrenal cortex and pituitary gland ${ }^{42}$. It is synthesised as an inactive precursor molecule lacking signal peptide, then processed by $\mathrm{ICE}^{42}$. IL-18 is active in complex with its receptor. IL-18 receptor (IL-18R) consists of binding chain IL-18R $\alpha$, formerly identified as the IL-1 receptor-related protein (IL-1Rrp), and a signalling chain IL-18R $\beta$. The signal transduction cascade is similar to that of IL-1. The IL-18R complex recruits IRAK and TRAF- $6{ }^{43}$. These events lead to activation of NF- $\kappa$ B. IL-18 induces IFN- $\gamma$ and its biological effects are similar to IL-12 in mediating $T_{h} 1$ response and activation of natural killer cells. It also induces gene expression and synthesis of TNF, IL-1, Fas ligand and of some chemokines ${ }^{44}$.

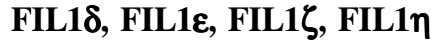

These novel members of IL-1 superfamily were recognised by searching the public EST databases relying on the sequence similarities ${ }^{2}$. Sequence alignment revealed approximately a $20-35 \%$ sequence identity between the IL-1 superfamily members. A most common shared amino acid motif is $\mathrm{F}\left(\mathrm{X}_{10-12}\right) \mathrm{FXS}(\mathrm{AVS}) \mathrm{XX}(\mathrm{PE})$ $\mathrm{XX}(\mathrm{FY})(\mathrm{LI})(\mathrm{CAS})$ (TC) with one-letter amino acid code, where $\mathrm{X}$ is any amino acid. According to the similarity, the members of the superfamily can be divided into three subgroups. The first includes IL-1 $\alpha$, IL-1 $\beta$, IL-18, the second IL-1Ra, FIL $\delta$ and third FIL $\zeta$, FIL $\varepsilon$, FIL $\eta^{2}$. The tertiary structure of the novel members is also a 12 -stranded $\beta$-trefoil, which is well conserved in IL-1. The major difference between FIL1 $\delta$, FIL1 $1 \varepsilon$, FIL1 $\zeta$ is in loops connecting the $\beta$ strands. The novel family members are expressed in different haematopoetic and non-haematopoetic cell types. All of them are expressed in activated monocytes and B cells, FIL1ع also in $\mathrm{T}$ cells. Their biologically activity is unknown.

\section{RELATIONSHIP BETWEEN IL-1 FAMILY MEMBERS}

The mechanism of action and relationship between IL-1 and their counterparts has several levels. In the synthesis pathway, the production of the agonists and antagonists is regulated at the level of pre-transcriptional processes, transcription, post-trancriptional mRNA splicing, mRNA stability, translation and processing. IL-1 $\beta$ is an auto-regulating protein, inducing its own expression in human PBMC and endothelial cells in vitro ${ }^{45}$. This auto-induction can be inhibited by IL-1 $\mathrm{Ra}$, thus suggesting IL-1Ra is a negative regulator of positive feedback loop of IL-1 production ${ }^{46}$. However, in IL-1Ra knockout and overproducing mice it was found, that IL-1Ra up-regulates the IL-1 serum levels during endotoxemia ${ }^{32}$. It is plausible that IL-1Ra in vivo acts both as a positive and negative regulator of IL-1 expression.

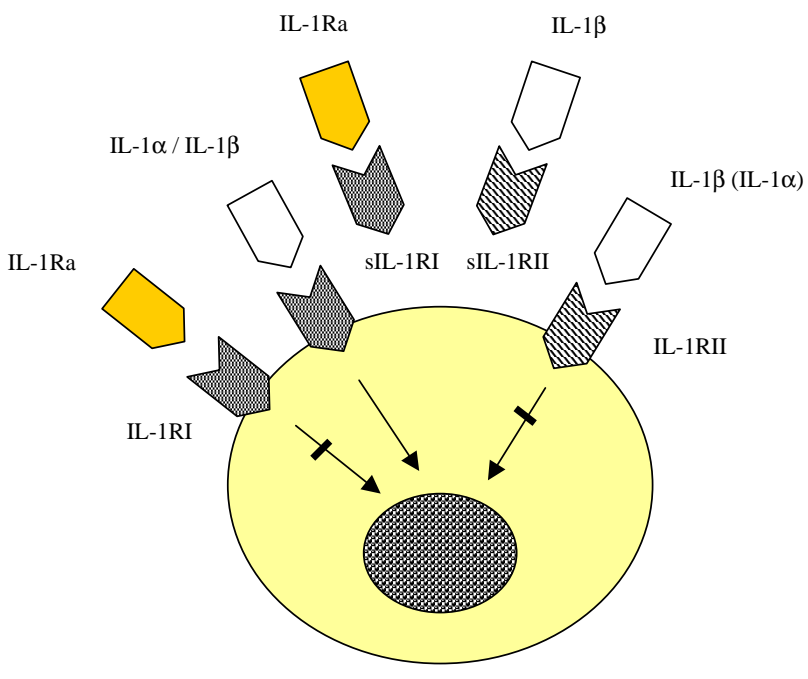

Fig. 1 Model of interaction between IL-1, IL-1Ra and IL-1 receptors. Arrows represent signal transduction. Abbreviations: IL- $1 \alpha$, interleukin-1 $\alpha$; IL-1 $\beta$, interleukin-1 $\beta$; IL-1Ra, IL-1 receptor antagonist; IL-1RI, IL-1 receptor type I; IL-1RII, IL-1 receptor type II; sIL1RI, soluble IL-1 receptor type I; sIL-2RII, IL-1 receptor type II.

Beyond these events the bioavailability and bioactivity of IL-1 is regulated by specific inhibitors, cell-bound or soluble IL-1 receptors (Figure 1). IL-1RI has approximately equal affinity for IL-1 $\alpha$, IL-1 $\beta$ and IL-1Ra ${ }^{10}$. Despite near equal affinities, IL-1Ra needs large molar excess (10- to 100-fold) to inhibit the IL-1 agonistic action $^{47}$. IL-1Ra associates with IL-1RI slower than IL-1, and IL-1 rather then IL-1Ra occupies the empty receptor. IL-1RII has the affinity for IL-1 100 -fold stronger than for IL-1Ra $\mathrm{R}^{48}$ and its preference range is IL-1 $\beta>$ IL-1 $\alpha>$ IL-1Ra ${ }^{11}$. Thus the IL-1RII blocks IL-1 $\beta$ binding to signal transducing IL-1RI. As for the soluble forms, sIL-1RI binds preferentially IL-1Ra to IL- $1 \alpha$ and IL-1 $\beta$. Under normal conditions it does not alter the availability of IL-1 $\beta$ to membrane-bound IL-1RI, but neutralises the antiinflammatory action of IL-1Ra. On the other hand sIL-1RII with great affinity to IL-1 $\beta$ sequesters IL-1 $\beta$ and disrupts its activity. The great excess of sIL-1RII to sIL-1RI in extracellular fluid supports the idea, that sIL-1RII, rather than sIL-1RI, is the major regulator of IL-1 $\beta$ activity ${ }^{11}$.

\section{IL-1 FAMILY IN DISEASE}

The pivotal role of IL-1 in various disorders has been demonstrated in numerous studies with human diseases or experimental animal models of disease. They have been summarised in previous reviews ${ }^{10,28}$. Beneficial effects of administration of recombinant IL-1Ra in animal models have enabled using IL-1Ra treatment in human clinical trials. 


\section{Autoimmune diseases}

The involvement of IL-1 in the pathogenesis of rheumatoid arthritis (RA) is now well accepted. IL-1 appears to be important in inflammation-induced erosive cartilage damage and bone resorption in animal polyarthritis models, but it is less involved in the early joint swelling and periarticular inflammation ${ }^{49,50}$. In rat type II collagen-induced arthritis with lesions analogous to those in human RA, IL-1 is a major mediator participating in all aspects of disease progression ${ }^{50}$. Clinical studies suggested a correlation between levels of IL-1 $\beta$ and parametres of joint damage ${ }^{51}$. Thus inhibiting the IL-1 activity may be beneficial in treatment of RA. The important regulatory role of IL-1Ra in disease has been shown in IL-1Ra deficient mice, where a chronic inflammatory arthropathy with autoimmunity has developed, resembling human $\mathrm{RA}^{52}$. Blocking IL-1 with anti-IL- $1 \alpha+\beta$ treatment during murine type II collagen-induced arthritis protects the cartilage and bone structures ${ }^{53}$. The administration of IL-1Ra to RA patients in clinical trials have resulted in decrease of inflammatory disease activity and may inhibit the progression of joint erosion $^{54}$.

In systemic lupus erythematosus (SLE) high serum concentration of IL-1Ra has been measured as a pathophysiologic feature of disease activity ${ }^{55}$. However, there are contradictory findings about the expression of IL-1 $\mathrm{Ra}$ by PBMC in response to adherent $\mathrm{IgG}$ in active SLE. Suzuki et al. (1995) report enhanced expression of IL-1Ra mRNA in freshly isolated monocytes, while recently a deficiency in Fcy-R-mediated production of IL-1Ra in monocytes from patients with active SLE compared with those with inactive disease was found ${ }^{56}$. This deficiency may contribute to immune-complex-mediated tissue damage in SLE.

The dermal fibroblasts from patients with systemic sclerosis (SSc) exhibit an aberrant constitutive expression of IL- $1 \alpha$ mRNA and contain intracellular proIL-1 $1 \alpha^{57}$. SSc fibroblasts are characteristic by increased production of IL- $1 \alpha$, IL- 6 and PDGF-A, the key mediators of collagen synthesis, which mediate an excessive extracellular matrix synthesis ${ }^{9}$.

IL-1 $\beta$ plays a crucial role also in "destructive" organ-specific autoimmunity in Hashimoto's thyreoiditis by induction of efficient autoantigen presentation via costimulatory molecules and Fas/FasL-mediated apoptosis of thyroid follicular cells ${ }^{58}$.

\section{Gastrointestinal tract}

In peripheral blood or biopsy specimen from patients with inflammatory bowel diseases (IBD) increased amounts of IL-1 and IL-1Ra have been measured ${ }^{59,60,61}$. The increased capacity of cultured colonic lamina propria mononuclear cells to produce IL-1 $\beta$ has been shown to predict acute relapses in Crohn's disease ${ }^{62}$. Both in ulcerative colitis and Crohn s disease a decreased ratio of mucosal IL-1Ra / IL-1 $\beta$ at protein and mRNA levels has been described, correlating with disease severity ${ }^{63}$. Even if the expression of IL-1Ra in intestinal mucosa is enhanced, its production is relatively low to that of IL-1 $\beta$ and this imbalance between IL-1 $\beta$ and IL-1Ra production appears to be decisive in IBD. The importance of IL-1Ra has been demonstrated in experimentally induced colitis in rabbits, where administration of antiIL-1Ra antibodies increased mortality and prolonged intestinal inflammatory responses ${ }^{64}$.

Higher serum levels of IL-1 $\beta$ and IL-1Ra were found also in chronic liver diseases. In HCV-related chronic autoimmune hepatitis an increased IL-1 / IL-1Ra mRNA ratio at tissue level appears to contribute to the development of more aggressive disease forms with higher grade of fibrosis ${ }^{65}$.

Using several animal models of acute pancreatitis (AP), high concentration of IL-1 in pancreatic parenchyma, but also in other organs were measured. It was found that IL-1 does not trigger acute pancreatitis, but plays important role in disease progression ${ }^{66}$.

\section{Lung}

In established acute respiratory distress syndrome (ARDS), elevated levels of both IL-1 $\beta$ and IL-1Ra were found in alveolar air space and plasma ${ }^{67,68,69}$. The systemic level of IL-1 $\beta$ seems to reflect the severity of the lung injury rather than the diagnosis in different lung diseases $^{70}$. The levels of IL-1 $\beta$ in BAL fluid from patients with ARDS did not differ between survivors and non-survivors, but low concentrations of anti-inflammatory cytokines IL-1Ra and IL-10 were associated with worse prognosis ${ }^{68}$. These observations support the hypothesis that inability to intensify the local anti-inflammatory activity early in the development of ARDS contributes to more severe lung injury and has prognostic significance. In animal ischemia/reperfusion acute lung injury model IL-1 mRNA in lung tissue is upregulated after transient lung ischemia in a time-dependent manner ${ }^{71}$. In loci of hypoxic vascular injury IL-1 participates in attraction of leukocytes. IL-1 $\beta$ in concert with $\mathrm{TNF} \alpha$ is considered to play a central role also in pathogenesis of acute pancreatitis associated $\mathrm{ARDS}^{72,73}$. Up-regulation of IL-1 and TNF $\alpha$ production within the lung parenchyma is present after intravenous infusion of sterile pancreatic ascites from AP animals free of IL-1 $\beta$, IL-6, IL- 8, TNF- $\alpha$, INF- $\gamma$ and LPS, thus suggesting that these mediators are not likely to be directly responsible for induction of ARDS during $\mathrm{AP}^{73}$. However, IL-1 and TNF- $\alpha$ genes are induced in a delayed fashion after the onset of acute pancreatitis and are required for development of sepsis associated ARDS.

Furthermore, high concentration of IL-1 $\beta$ in bronchoalveolar lavage (BAL) fluid have been found in allergic responses and bronchial asthma ${ }^{74}$. The cytokine release in the airways results from modulatory interaction between epithelial cells, alveolar macrophages and infiltrating monocytes.

In BAL fluid of patients with cryptogenic fibrosing alveolitis (CFA) an increased level of IL-1Ra has been reported accompanied by proportional elevation of IL-1 $\beta^{75}$. A significant increase of IL-1Ra was also present in 
tissue homogenates, but without concomitant elevation of IL-1 $\beta$. Hyperplastic type II pneumocytes, pulmonary fibroblasts and macrophages have been identified as the primary source of IL-1Ra. These findings demonstrate production of IL-1Ra by non-immune cells and suggest a possible role of IL-1Ra in disease progression through attenuation of IL-1-dependent normal tissue remodelling during resolution and tissue repair. In contrast, other studies describe decreased amounts of IL-1Ra in culture supernatants from CFA patients ${ }^{76}$. There are no differences in number or affinity of type I IL-1 signal transducing receptor on lung fibroblasts between CFA patients and controls ${ }^{77}$.

In sarcoidosis, alveolar macrophages in vitro spontaneously release greater amounts of IL-1 $\beta$ in active disease in comparison with cells from patients with inactive disease and from healthy controls ${ }^{78}$.

\section{Sepsis}

Serum levels of IL-1 $\beta$ and IL-1Ra are significantly elevated in severe sepsis and the higher levels of IL-1Ra are associated with an early hemodynamic deteriora$\operatorname{tion}^{79}$. Both the pro- and anti-inflammatory response is augmented in sepsis with imbalance of counteracting mediator systems. Studies with IL-1RI KO mice showed that IL-1 significantly contributes to sepsis-induced endothelial damage ${ }^{80}$. IL-1 $\beta$, derived from Kupffer cells, appears to be directly or indirectly responsible also for hepatocellular dysfunction occurring early after the onset of sepsis ${ }^{81}$.

\section{Central nervous system}

IL-1 $\beta$ has been implicated as a mediator of hypoxicischemic (HI) brain injury, both in experimental models and in human ${ }^{82}$. Brain IL-1 $\beta$ activity and mRNA levels increase acutely after unilateral cerebral $\mathrm{HI}$ in neonatal rats $^{83}$. The absence of IL-1 $\beta$ processing by ICE in neonatal ICE-deficient mice have increased the resistance to HI brain injury. These findings suggest that ICE is crucial in the evolution of ischemic brain damage leading to neurologic deficits in perinatal period ${ }^{82}$.

The importance of ICE has been demonstrated also in early phase of immune-mediated demyelination of the CNS, where reduction of experimental autoimmune encephalomyelitis incidence and severity in ICE -/- mice was observed ${ }^{84}$.

\section{GENE POLYMORPHISMS OF THE IL-1 COMPLEX}

\section{Influence of gene polymorphisms on IL-1 protein expression}

Cytokines and cytokine receptors are generally highly conserved in their coding regions. Polymorphisms within the exons directly affect the protein structure and possibly result in alteration of protein function. Mutations not affecting the sequence of amino acids in polypeptide chains may influence protein production on diffe- rent transcriptional or posttranscriptional levels ${ }^{85}$. They can alter the structure of genes' regulatory elements with binding sites for transcriptional factors, transcription rate, mRNA splicing or mRNA stability. For example, in case of VNTR polymorphism of IL- $1 \alpha$ gene in intron 6 , each of the repeat sequences contains binding sites for transcription factor SP1, an imperfect copy of a viral enhancer element and an inverse and complementary sequence of a glucocorticoid-responsive element ${ }^{86}$. Table 2 contains the known gene polymorphisms of IL-1 complex.

Table 2. The gene polymorphisms of IL-1 family members $^{85,86,97,98,99,100,101 .}$

\begin{tabular}{|c|c|c|c|c|c|}
\hline \multirow[t]{2}{*}{ Gene } & \multicolumn{3}{|c|}{ Single base substitution } & \multicolumn{2}{|r|}{ VNTR polymorphism } \\
\hline & position & exchange & RFLP & position & repeat sequence \\
\hline IL-1 $\alpha$ & $\begin{array}{c}-889 \\
+4345\end{array}$ & $\begin{array}{l}\mathrm{C} / \mathrm{T} \\
\mathrm{T} / \mathrm{G}\end{array}$ & & intron 6 & $\begin{array}{l}46 \text { bp }(5,8,9,12,15,18 \text { repeats) } \\
\text { dinucleotide repeats } \\
\text { (TTA) repeats }\end{array}$ \\
\hline IL-1 $\beta$ & $\begin{array}{c}-511 \\
+3953 \\
-31 \\
\mathrm{nt} 5810 \\
\end{array}$ & $\begin{array}{l}\mathrm{C} / \mathrm{T} \\
\mathrm{C} / \mathrm{T} \\
\mathrm{T} / \mathrm{C} \\
\mathrm{G} / \mathrm{A} \\
\end{array}$ & $\begin{array}{c}\text { AvaI } \\
\text { TaqI } \\
\text { AluI } \\
\text { BsoFI } \\
\end{array}$ & & \\
\hline IL-1Ra & $\begin{array}{c}+2016 \\
\text { nt8006 } \\
\text { nt8061 } \\
\text { nt9589 } \\
\text { nt11100 }\end{array}$ & $\begin{array}{l}\mathrm{T} / \mathrm{C} \\
\mathrm{T} / \mathrm{C} \\
\mathrm{C} / \mathrm{T} \\
\mathrm{A} / \mathrm{T} \\
\mathrm{T} / \mathrm{C} \\
\end{array}$ & $\begin{array}{c}\text { MspI } \\
\text { MwoI } \\
\text { SspI } \\
\text { MspA1I }\end{array}$ & intron 2 & 86 bp $(2,3,4,5,6$ repeats $)$ \\
\hline IL-1RI & $\begin{array}{l}\text { exon 1B } \\
\text { exon } 1 \mathrm{C} \\
\text { exon } 1 \mathrm{C} \\
\text { intron } 1 \mathrm{~B}\end{array}$ & $\begin{array}{l}\mathrm{C} / \mathrm{T} \\
\mathrm{A} / \mathrm{T} \\
\mathrm{C} / \mathrm{A} \\
\mathrm{A} / \mathrm{G}\end{array}$ & $\begin{array}{l}\text { PstI (A) } \\
\text { PstI (B) } \\
\\
\text { BsrBI } \\
\text { MspI }\end{array}$ & & \\
\hline
\end{tabular}

Abbreviations: RLFP, Restriction Length Fragment Polymorphism; VNTR, Variable Number of Tandem Repeats; IL-1a, interleukin-1a; IL-1 $\beta$, interleukin-1 $\beta$; IL-1Ra, IL-1 receptor antagonist; IL-1RI, IL-1 receptor type I; C, cytosine; T, thymine; A, adenine; G, guanine.

In vitro and in vivo secretion of IL-1 $\beta$ and IL-1Ra exhibits interindividual variability associated with gene polymorphisms. The presence of allele 2 of IL-1 $\beta$ single base substitution polymorphism at position +3953 may increase in vitro LPS-stimulated IL-1 $\beta$ production by PMBC, where an allele-dosage effect was observed ${ }^{87}$. Allele 2 of IL-1Ra VNTR polymorphism (IL-1RN*2) is suggested to be the major up-regulator of IL-1 $1 \beta^{88}$ and IL-1Ra in vitro levels in stimulated mononuclear cell cultures $^{89}$. However, contradictory observations have been described. The carriage of IL-1RN*2 has been associated with decreased production of total IL-1Ra by PBMC from ethnically different ulcerative colitis patients and healthy controls ${ }^{90}$. IL-1 $\beta+3953$ and -511 single base substitution polymorphisms also participate in the regulation of IL-1Ra in vivo production and they show a cooperative effect with IL-1RN*291. IL-1RN*2 phenotype increases IL-1Ra levels in vivo in healthy population only in the presence of allele 2 of IL-1 $\beta$ -511 . Allele 2 of IL-1 $\beta-511$ and IL-1RN*2 are considered to represent a "high secretor" phenotype leading to increased proinflammatory activity in autoimmune and infectious diseases ${ }^{92}$. More than the absolute amount of IL-1 $\beta$ or IL-1Ra, the IL-1 $\beta$ / IL-1Ra ratio is decisive in inflammatory response. 
Table 3. Associations of IL-1 complex gene polymorphisms with disease

\begin{tabular}{|c|c|c|c|}
\hline Disease & Gene polymorphism & Association & Reference \\
\hline alopecia areata & IL-1RN & +4* & 102 \\
\hline \multirow[t]{2}{*}{ autoimmune hepatitis } & IL-1 $\beta+3953$ & - & 103 \\
\hline & IL-1RN & - & 103 \\
\hline autoimmune hypothyroidism & IL-1RN & - & 104 \\
\hline CMV seronegativity & IL-1RN, TNF $\alpha-308^{\#}$ & + & 105 \\
\hline \multirow[t]{3}{*}{ Crohn's disease } & IL-1 $\beta-511$ & - & 94 \\
\hline & IL-1RN & - & 106 \\
\hline & IL-1RN & - & 94 \\
\hline cryptogenic fibrosing alveolitis & IL-1RN & + & 107 \\
\hline \multirow[t]{7}{*}{ diabetic nephropathy in IDDM } & IL- $1 \alpha-889$ & - & 108 \\
\hline & IL- $1 \beta+3953$ & + & 108 \\
\hline & IL- $1 \beta+3953$ & - & 109 \\
\hline & IL-1RI (PstI) & - & 109 \\
\hline & IL-1RN & + & 110 \\
\hline & IL-1RN & - & 108 \\
\hline & IL-1RN & - & 109 \\
\hline early postmenopausal bone loss & IL-1RN & + & 111 \\
\hline \multirow{2}{*}{$\begin{array}{l}\text { early-onset pauciarticular } \\
\text { juvenile rheumatoid arthritis }\end{array}$} & IL- $1 \alpha-889$ & + & 112 \\
\hline & IL- $1 \alpha-889$ & - & 113 \\
\hline psoriasis & IL-1RN & $t^{*}$ & 114 \\
\hline EBV seronegativity & IL- $1 \beta-511$ & + & 115 \\
\hline \multirow[t]{2}{*}{ Graves'disease } & IL-1RN & - & 104 \\
\hline & IL-1RN & - & 116 \\
\hline Henoch-Schönlein nephritis & IL-1RN & + & 117 \\
\hline IDDM & IL-1RI (PstI) & + & 118 \\
\hline lichen sclerosus & IL-1RN & + & 119 \\
\hline \multirow[t]{3}{*}{ multiple sclerosis } & IL-1RN & + & 120 \\
\hline & IL-1RN & $+*$ & 121 \\
\hline & $\mathrm{IL}^{-1} \beta+3953, \mathrm{IL}-1 \mathrm{RN}{ }^{\#}$ & $+^{*}$ & 122 \\
\hline \multirow[t]{2}{*}{ myasthenia gravis } & IL- $1 \beta+3953$ & + & 123 \\
\hline & IL-1RN & - & 123 \\
\hline \multirow[t]{2}{*}{ periodontitis } & IL-1 $\beta+3953$ & $+*$ & 124 \\
\hline & IL-1 $\alpha-889$, IL-1 $\beta+3953^{\#}$ & $+*$ & 125 \\
\hline \multirow[t]{2}{*}{ primary Sjögren’s syndrome } & IL-1RN & $+^{*}$ & 126 \\
\hline & IL-1RN & - & 127 \\
\hline rheumatoid arthritis & IL-1 $\alpha-889$ & $+*$ & 128 \\
\hline $\begin{array}{l}\text { secondary acute myeloid } \\
\text { leukaemia }\end{array}$ & IL-1RN & - & 129 \\
\hline \multirow{2}{*}{$\begin{array}{l}\text { leukaemia } \\
\text { severe sepsis }\end{array}$} & $\mathrm{IL}-1 \beta+3953$ & - & 130 \\
\hline & IL-1RN & + & 130 \\
\hline \multirow[t]{3}{*}{ schizophrenia } & IL-1 $\beta+3953$ & - & 131 \\
\hline & IL- $1 \beta-511$ & - & 132 \\
\hline & IL-1 $\alpha-889$, IL-1 $\beta-511$, IL-1RN ${ }^{\#}$ & + & 133 \\
\hline \multirow[t]{2}{*}{ systemic lupus erythematosus } & IL-1RN & + & 134 \\
\hline & IL-1RN & - & 104 \\
\hline tuberculosis & IL-1RN & + & 135 \\
\hline \multirow[t]{9}{*}{ ulcerative colitis } & $\mathrm{IL}-1 \beta+3953$ & - & 136 \\
\hline & IL-1 $\beta+3953$ & - & 94 \\
\hline & IL- $1 \beta-511$ & $+*$ & 137 \\
\hline & IL- $1 \beta-511$ & - & 94 \\
\hline & IL-1RN & $t^{*}$ & 138 \\
\hline & IL-1RN & $t^{*}$ & 94 \\
\hline & IL-1RN & + & 90 \\
\hline & IL-1RN & - & 95 \\
\hline & IL-1RN & - & 106 \\
\hline
\end{tabular}

\# haplotype, * disease severity

Abbreviations: IL- $1 \alpha-889$, single base substitution polymorphism at position -889 in the IL-1 $\alpha$ gene; IL-1 $\beta-511$, single base substitution polymorphism at position -511 in the IL-1 $\beta$ gene; IL-1 $\beta+3953$, single base substitution polymorphism at position +3953 in the IL-1 $\beta$ gene; IL-1RN, variable number tandem repeat polymorphism in intron 2 of the IL-1Ra gene; TNF $\alpha-308$, single base substitution polymorphism at position -308 in the tumour necrosis factor-a gene; IL-1RI (PstI), PstI polymorphism in the IL-1 receptor type I gene.

\section{Association of IL-1 complex gene polymorphisms with human diseases}

The investigated associations between gene polymorphisms of IL-1 complex and human diseases are listed in the Table 3 . The polymorphisms of IL-1 family genes are implicated especially in the development of autoimmune, chronic inflammatory diseases and malignancies. In many cases the frequency of an allele or a haplotype does not differ between healthy controls and patients, but there is a significant difference in distinct forms of disease according to the severity and/or progression. Gene polymorphisms may be markers of susceptibility, severity or may predict the clinical outcome. Particular ethnic differences in distribution of distinct alleles of gene polymorphisms have been observed. In ulcerative colitis (UC), investigated in Caucasoid populations, a weak (patients from U.K.) or no significant (patients from France, Germany, Netherlands) association was found between IL-1RN*2 and susceptibility to $\mathrm{UC}^{93,94,95,96}$. In contrast, a strong association has been described in Hispanic-Caucasian and Jewish-Caucasian ethnic groups ${ }^{90}$. It is also suggested, that IL-1RN*2 is not directly responsible for the disease predisposition, but is in linkage disequilibrium with another DNA sequence variation within or close to the IL-1RN gene, which is more directly responsible for susceptibility of an individual to UC.

\section{CONCLUSION}

Interleukin-1 family is a rather complex self-regulating system, which affects almost all cell types in organism. Its members have been shown to be important either in health and in the development of various disorders. Elucidating the mechanism of action of this cytokine family may help to understand the aetiology and pathophysiology of human diseases and subsequently establish novel strategies for primary prevention and/or therapeutical intervention. Measuring IL-1 production in disease states may serve as a marker of the clinical course of disease or therapeutic efficacy. Since IL-1 family members have been proposed to be the candidate genes in many polygenic disorders, their gene polymorphisms are important in obtaining an insight into the genetic background of human immunopathologies.

\section{ACKNOWLEDGEMENTS}

The author thanks to Dr. M. Petřek for his complex guidance throughout preparation of this manuscript and also to Dr. J. Drábek for his critical review of this paper. The work was supported by Grant Agency of Czech Republic (No 310/99/1676) and Medical Faculty of Palacký University (No 14501103).

\section{REFERENCES}

1. Okamura, H., Tsutsi, H., Komatsu, T., Yutsudo, M., Hakura, A., Tanomoto, T. et al. (1995) Cloning of a new cytokine that induces IFN-gamma production by T cells. Nature, 378, 88-91.

2. Smith, D. E., Renshaw, B. R., Ketchem, R. R., Kubin, M., Garka, K. E., Sims, J. E. (2000) Four new members expand the interleukin-1 superfamily. J. Biol. Chem., 275, 1169-1175.

3. Dale, M., Nicklin, M. J. H. (1999) Interleukin-1 receptor cluster: gene organization of IL1R2, IL1R1, IL1RL2 (IL-1Rrp2), IL1RL1 (T1/ST2), and IL18R1 (IL-1Rrp) on human chromosome 2q. Genomics, 57, 177-179. 
4. Nicklin, M. J., Weith, A., Duff, G. W. (1994) A physical map of the region encompassing the human interleukin-1 alpha, interleukin-1 beta, and interleukin-1 receptor antagonist genes. Genomics, 19, 382-4.

5. Nolan, K. F., Greaves, D. R., Waldmann, H. (1998) The human interleukin 18 gene maps to $11 \mathrm{q} 22.2-\mathrm{q} 22.3$, closely linked to DRD2 gene locus and distinct from mapped IDDM loci. Genomics, 51, 161-163.

6. Cox, A., Camp, N. J., Nicklin, M. J. H., di Giovine, F. S., Duff, G. W. (1998) An analysis of linkage disequilibrium in the interleukin-1 gene cluster, using a novel grouping method for multiallelic markers. Am. J. Hum. Genet., 62, 1180-1188.

7. Steinkasserer, A., Spurr, N. K., Cox, S., Jeggo, P., Sim, R. B. (1992) The human IL-1 receptor antagonist gene (IL1RN) maps to chromosome $2 \mathrm{q} 14-\mathrm{q} 21$, in the region of IL-1 alpha and IL-1 beta loci. Genomics, 13, 654-7.

8. Hauser, C., Saurat, J. H., Schmitt, A., Jaunin, F., Dayer, J. M. (1986) Interleukin 1 is present in human epidermis. J. Immunol., 136, 3317-23.

9. Kawaguchi, Y., Hara, M., Wright, T. M. (1999) Endogenous IL-1 $\alpha$ from systemic sclerosis fibroblasts induces IL-6 and PDGF-A. J. Clin. Invest., 103, 1253-60.

10. Dinarello, C. A. (1996) Biologic basis for interleukin-1 in disease. Blood, 87, 2095-2147.

11. Watkins, L. R., Hansen, M. K., Nguyen, K. T., Lee, J. E., Maier, S. F. (1999) Dynamic regulation of the proinflammatory cytokine, interleukin-1 $\beta$ : molecular biology for non-molecular biologists. Life Sci., 65, 449-481.

12. Schindler, R., Clark, B. D., Dinarello, C. A. (1990) Dissociation between interleukin-1 beta mRNA and protein synthesis in human peripheral blood mononuclear cells. J. Biol. Chem., 265, 10232-7.

13. Stevenson, F. T., Bursten, S. L., Fanton, C., Locksley, R. M., Lovett, D. H. (1993) The $31-\mathrm{kD}$ a precursor of interleukin- $1 \alpha$ is myristoylated on specific lysines within the $16-\mathrm{kDa}$ N-terminal propiece. Proc. Natl. Acad. Sci. USA, 90, 7245.

14. Kobayashi, Y., Yamamoto, K., Saido, T., Kawasaki, H., Oppenheim, J. J., Matsushima, K. (1990) Identification of calciumactivated neutral protease as a processing enzyme of human interleukin 1 alpha. Proc. Natl. Acad. Sci. USA, 87, 5548.

15. Wewers, M. D., Winnard, A. V., Dare, H. A. (1999) Endotoxinstimulated monocytes release multiple forms of IL-1 $\beta$, including a pro-IL-1 $\beta$ form whose detection is affected by export. $\mathbf{J}$. Immunol., 162, 4858-4863.

16. Wilson, K. P., Black, J. A., Thomson, J. A., Kim, E. E., Griffith, J. P., Navia, M. A. et al. (1994) Structure and mechanism of interleukin-1 beta converting enzyme. Nature, 370, 270-5.

17. Schönbeck, U., Mach, F., Libby, P. (1998) Generation of biologically active IL-1 $\beta$ by matrix metalloproteinases: A novel caspase1 -independent pathway of IL-1 $\beta$ processing. J. Immunol., 161, 3340-3346.

18. Maier, J. A. M., Statuto, M., Ragnotti, G. (1994) Endogenous interleukin 1 alpha must be transported to the nucleus to exert its activity in human endothelial cells. Mol. Cell Biol., 14, 1845.

19. Horai, R., Asano, M., Sudo, K., Kanuka, H., Suzuki, M., Nishihara, M. et al. (1998) Production of mice deficient in genes for interleukin (IL)-1alpha, IL-1 beta, IL-1alpha/beta, and IL-1 receptor antagonist shows that IL-1beta is crucial in turpentineinduced fever development and glucocorticoid secretion. J. Exp. Med., 187, 1463-75.

20. Fantuzzi, G., Dinarello, C. A. (1996) The inflammatory response in interleukin-1beta-deficient mice: comparison with other cytokine-related knock-out mice. J. Leukoc. Biol., 59, 489-93.

21. Kozak, W., Kluger, M. J., Soszynski, D., Conn, C. A., Rudolph, K., Leon, L. R. et al. (1998) IL-6 and IL-1 beta in fever. Studies using cytokine-deficient (knockout) mice. Ann. N. Y. Acad. Sci., 856, 33-47.

22. Labow, M., Schuster, D., Zetterstrom, M., Nunes, P., Terry, R., Cullinan, E. B. et al. (1997) Absence of IL-1 signalling and reduced inflammatory response in IL-1 type I receptor-deficient mice. J. Immunol., 159, 2452-61.

23. Butcher, C., Steinkasserer, A., Tejura, S., Lennard, A. C. (1994) Comparison of two promoters controlling expression of secreted or intracellular IL-1 receptor antagonist. J. Immunol., 153, 701-11.
24. Jenkins, J. K., Drong, R. F., Shuck, M. E., Bienkowski, M. J., Slightom, J. L., Arend, W. P. et al. (1997) Intracellular IL-1 receptor antagonist promoter. J. Immunol., 158, 748-755.

25. Roux-Lombard, P. (1998) The interleukin-1 family. Eur. Cytokine Netw., 9(4), 565-76.

26. Malyak, M., Guthridge, J. M., Hance, K. R., Dower, S. K., Freed, J. H., Arend, W. P. (1998) Characterization of a low molecular weight isoform of IL-1 receptor antagonist. J. Immunol., 161, 1997-2003.

27. Muzio, M., Polentarutti, N., Sironi, M., Poli, G., de Gioia, L., Introna, M. et al. (1995) Cloning and characterization of a new isoform of the interleukin-1 receptor antagonist. J. Exp. Med., 182, 623-628.

28. Arend,W. P., Malyak, M., Guthridge, C. J., Gabay, C. (1998) Interleukin-1 receptor antagonist: Role in biology. Annu. Rev. Immunol., 16, 27-55.

29. Malyak, M., Smith, M. F., Abel, A. A., Hance, K. R., Arend, W. P. (1998) The differential production of three forms of IL-1 receptor antagonist by human neutrophils and monocytes. J. Immunol., 161, 2004-2010.

30. Watson, J. M., Lofquist, A. K., Rinehart, C. A., Olsen, J. C., Makarov, S. S., Kaufman, D. G. et al. (1995) The intracellular IL-1 receptor antagonist alters IL-1-inducible gene expression without blocking exogenous signaling by IL-1 $\beta$. J. Immunol., 155, 4467-4475.

31. Higgins, G. C., Wu, Y., Postethwaite, A. E. (1999) Intracellular IL-1 receptor antagonist is elevated in human dermal fibroblasts that overexpresses intracellular precursor IL-1 $\alpha$. J. Immunol., 163, 3969-3975.

32. Hirsch, E., Irikura, V. M., Paul, S. M., Hirsh, D. (1996) Functions of interleukin-1 receptor antagonist in gene knockout and overproducing mice. Proc. Natl. Acad. Sci., 93, 11008-11013.

33. Cullinan, E. B., Kwee, L., Nunes, P., Shuster, D. J., Ju, G., McIntyre, K. W. et al. (1998) IL-1 receptor accessory protein is an essential component of the IL-1 receptor. J. Immunol., 161, 5614-5620.

34. Sims, J. E., Giri, J. G., Dower, S. K. (1994) The two interleukin1 receptors play different roles in IL-1 actions. Clin. Immunol. Immunopathol., 72, 9-14.

35. Lang, D., Knop, J., Wesche, H., Raffetseder, U., Kurrle, R., Boraschi, D. et al. (1998) The type II IL-1 receptor interacts with the IL-1 receptor accessory protein: A novel mechanism of regulation of IL-1 responsiveness. J. Immunol., 161, 6871-6877.

36. Colotta, F., Saccani, S., Giri, J. G., Dower, S. K., Sims, J. E., Introna, M., Mantovani, A. (1996) Regulated expression and release of the IL-1 decoy receptor in human mononuclear phagocytes. J. Immunol., 156, 2534-2541.

37. Arend, W. P., Malyak, M., Smith, M. F. Jr., Whisenand, T. D., Slack, J. L., Sims, J. E. et al. (1994) Binding of IL-1 alpha, IL-1 beta, and IL-1 receptor antagonist by soluble IL-1 receptors and levels of soluble IL-1 receptors in synovial fluid. J. Immunol., 153, 4766-74.

38. Cao, Z., Henzel, W. J., Gao, X. (1996) IRAK: A kinase associated with interleukin-1 receptor. Science, 271, 1128-1131.

39. Muzio, M., Jian, N., Ping, F., Dixit, V. M. (1997) IRAK (Pelle) family member IRAK-2 and MyD88 as proximal mediators of IL1 signaling. Science, 278, 1612-1615.

40. Wesche, H., Gao, X., Li, X., Kirschning, C. J., Stark, G. R., Cao, Z. (1999) IRAK-M is as novel member of the Pelle/interleukin-1 receptor-associated kinase (IRAK) family. J. Biol. Chem., 274, 19403-10.

41. Singh, R., Wang, B., Shirvaikar, A., Khan, S., Kamat, S., Schelling, J. R. et al. (1999) The IL-1 receptor and Rho directly associate to drive cell activation in inflammation. J. Clin. Invest., 103, 1561-1570.

42. Fantuzzi, G., Dinarello, C. A. (1999) Interleukin-18 and interleukin-1 $\beta$ : two cytokine substrates for ICE (caspase-1). J. Clin. Immunol., 19, 1-11.

43. Kojima, H., Takeuchi, M., Ohta, T., Nishida, Y., Arai, N., Ikeda, M. et al. (1998) Interleukin-18 activates the IRAK-TRAF6 pathway in mouse EL-1 cells. Biochem. Biophys. Res. Commun., 244, 183-6.

44. Dinarello, C. A. (1999) IL-18: A Th1-inducing, proinflammatory cytokine and a new member of the IL-1 family. J. Allergy Clin. Immunol., 103(1Pt1), 11-24. 
45. Dinarello, C. A., Ikejama, T., Warner, S. J. C., Orencole, S. F. Lonnemann, G., Cannon, J. G., Libby, P. (1987) Interleukin 1 induces interleukin 1. I. Induction of circulating interleukin 1 in rabbits in vivo and in human mononuclear cells in vitro. $\mathrm{J}$. Immunol., 139, 1902-1910.

46. Granowitz, E. V., Clark, B. D., Vannier, E., Callahan, M. V., Dinarello, C. A. (1992) Effects of interleukin-1 (IL-1) blockade on cytokine synthesis: I. IL-1 receptor antagonist inhibits IL-1induced cytokine synthesis and blocks the binding of IL-1 to its type II receptor on human monocytes. Blood, 79, 2356-2363.

47. Arend, W. P., Welgus, H. G., Thompson, R. C., Eisenberg, S. P. (1990) Biological properties of recombinant human monocytederived interleukin 1 receptor antagonist. J. Clin. Invest., 85, 1694-7.

48. Granowitz, E. V., Clark, B. D., Mancilla, J., Dinarello, C. A (1991) Interleukin-1 receptor antagonist competetively inhibits the binding of interleukin-1 to the type II interleukin-1 receptor. J. Biol. Chem., 266, 14147-50.

49. van den Berg, W. B., Bresnihan, B. (1999) Pathogenesis of joint damage in rheumatoid arthritis: evidence of a dominant role for interleukin-1. Best Pract. Res. Clin. Rheumatol., 13, 577-97.

50. Bendele, A., McBee, T., Sennello, G., Frazier, J., Chlipala, E. et al. (1999) Efficacy of sustained blood levels of interleukin-1 receptor antagonist in animal models of arthritis. Arthritis Rheum., 42, 498-506.

51. van den Berg, W. B., Joosten, L. A., Kollias, G., van den Loo, F. A. (1999) Role of tumour necrosis factor alpha in experimental arthritis: separate activity of interleukin 1 beta in chronicity and cartilage destruction. Ann. Rheum. Dis., 58 Suppl 1, 140-8.

52. Horai, R., Saijo, S., Tanioka, H., Nakae, S., Sudo, K., Okahara A. et al. (2000) Development of chronic inflammatory arthropathy resembling rheumatoid arthritis in interleukin 1 receptor antagonist-deficient mice. J. Exp. Med., 191, 313-20.

53. Joosten, L. A. B., Helsen, M. M. A., Saxne, T., van de Loo, F. A. J., Heinegard, D., van den Berg, W. B. (1999) IL-1 $\alpha \beta$ blockade prevents cartilage and bone destruction in murine type II collagen-induced arthritis, whereas TNF- $\alpha$ blockade only ameliorates joint inflammation. J. Immunol., 163, 5049-5055.

54. Bresnihan, B., Alvaro-Gracia, J. M., Cobby, M., Doherty, M., Domljan, Z., Emery, P. et al. (1998) Treatment of rheumatoid arthritis with recombinant human interleukin-1 receptor antagonist. Arthritis Rheum., 41, 2196-2204.

55. Suzuki, H., Takemura, H., Kashiwagi, H. (1995) Interleukin-1 receptor antagonist in patients with active systemic lupus erythematosus. Arthritis Rheum., 38, 1055-1059.

56. Andersen, L. S., Petersen, J., Svenson, M., Bendtzen, K. (1999) Production of IL-1beta, IL-1 receptor antagonist and IL-10 by mononuclear cells from patients with SLE. Autoimmunity, 30 , 235-42.

57. Kawaguchi, Y. (1994) IL-1 alpha gene expression and protein production by fibroblasts from patients with systemic sclerosis. Clin. Exp. Immunol., 97, 445-50.

58. Paolieri, F., Salmaso, C., Battifora, M., Montagna, P., Pesce, G. Bagnasco, M., Richiusa, P. (1999) Possible pathogenetic relevance of interleukin1 beta in "destructive" organ-specific autoimmune disease (Hashimoto s thyroiditis). Ann. N. Y. Acad. Sci. $876,221-8$.

59. Reinecker, H. C., Steffen, M., Witthoeft, T., Pflueger, I., Schreiber, S., MacDermott, R. P., Raedler, A. (1993) Enhanced secretion of tumour necrosis factor-alpha, IL-6, and IL-1 beta by isolated lamina propria mononuclear cells from patients with ulcerative colitis and Crohn's disease. Clin. Exp. Immunol., 94, 174-81.

60. Nakamura, M., Saito, H., Kasanuki, J., Tamura, Y., Yoshida, S (1992) Cytokine production in patients with inflammatory bowel disease. Gut, 33, 933-7.

61. Nishiyama, T., Mitsuyama, K., Toyonaga, A., Sasaki, E., Tanikawa, K. (1994) Colonic mucosal interleukin 1 receptor antagonist in inflammatory bowel disease. Digestion, 55, 368-73.

62. Schreiber, S., Nikolaus, S., Hampe, J., Hamling, J., Koop, I., Groessner, B. et al. (1999) Tumour necrosis factor $\alpha$ and interleukin $1 \beta$ in relapse of Crohn's disease. Lancet, 353, 459-461.

63. Casini-Raggi, V., Kam, L., Chong, Y. J., Fiocchi, C., Pizarro, T. T., Cominelli, F. (1995) Mucosal imbalance of IL-1 and IL-1 receptor antagonist in inflammatory bowel disease. A novel mechanism of chronic intestinal inflammation. J. Immunol., 154, 2434-40.

64. Ferretti, M., Casini-Raggi, V., Pizarro, T. T., Eisenberg, S. P., Nast, C. C., Cominelli, F. (1994) Neutralization of endogenous IL-1 receptor antagonist exacerbates and prolongs inflammation in rabbit immune colitis. J. Clin. Invest., 94, 449-453.

65. Gramantieri, L., Casali, A., Trere, D., Gaiani, S., Piscaglia, F., Chieco, P. et al. (1999) Imbalance of IL-1 $\beta$ and IL-1 receptor antagonist mRNA in liver tissue from hepatitis $\mathrm{C}$ virus (HCV)related chronic hepatitis. Clin. Exp. Immunol., 115, 515-520.

66. Norman, J. (1998) The role of cytokines in the pathogenesis of acute pancreatitis. Am. J. Surg., 175, 76-83.

67. Suter, P. M., Suter, S., Girardin, E., Roux-Lombard, P., Grau, G. E., Dayer, J. M. (1992) High bronchoalveolar levels of tumor necrosis factor and its inhibitors, interleukin-1, interferon, and elastase, in patients with adult respiratory distress syndrom after trauma, shock, or sepsis. Am. Rev. Respir. Dis., 145, 1016-22.

68. Donelly, S. C., Strieger, R. M., Reid, P. T., Kunkel, S. L., Burdick, M. D., Armstrong, I. et al. (1996) The association between mortality rates and decreased concentrations of interleukin-10 and interleukin-1 receptor antagonist in the lung fluids of patients with the adult respiratoty distress syndrome. Ann. Intern. Med., 125, 191-196.

69. Pugin, J., Ricou, B., Steinberg, K. P., Suter, P. M., Martin, T. R. (1996) Proinflammatory activity in bronchoalveolar lavage fluid from patients with ARDS, a prominent role for interleukin-1. Am. J. Respir. Crit. Care Med., 153, 1850-1856.

70. Bauer, T. T., Monton, C., Torres, A., Cabello, H., Fillela, X. Maldonado, A. et al. (2000) Comparison of systemic cytokine levels in patients with acute respiratory distress syndrom, severe pneumonia, and controls. Thorax, 55, 46-52.

71. Chang, D. M., Hsu, K., Ding, Y. A., Chiang, C. H. (1997) Interleukin-1 in ischemia-reperfusion acute lung injury. Am. J. Respir. Crit. Care Med., 156, 1230-1234

72. Montravers, P., Chollet-Martin, S., Marmuse, J. P., GougerotPocidale, M. A., Desmonts, J. M. (1995) Lymphatic release of cytokines during acute lung injury complicating acute pancreatitis. Am. J. Respir. Crit. Care Med., 152, 1527-33.

73. Denham, W., Yang, J., Norman, J. (1997) Evidence for an unknown component of pancreatic ascites that induces adult respiratory distress syndrome through an interleukin-1 and tumor necrosis factor-dependent mechanism. Surgery, 122, 295-302.

74. Hastie, A. T., Everts, K. B., Cho, S. K., Zangrilli, J., Shaver, J. R., Pollice, M. B. et al. (1996) IL-1 $\beta$ release from cultured bronchial epithelial cells and bronchoalveolar lavage cells from allergic and normal humans following segmental challenge with ragweed. Cytokine, 8, 730-738.

75. Smith, D. R., Kunkel, S. L., Standiford, T. J., Rolfe, M. W., Lynch III J. P., Arenberg, D. A. et al. (1995) Increased interleukin-1 receptor antagonist in idiopathic pulmonary fibrosis. Am. J. Respir. Crit. Care Med., 151, 1965-1973.

76. Nagai, S., Aung, H., Takeuchi, M., Kusume, K., Izumi, T. (1991) IL-1 and IL-1 inhibitory activity in the culture supernatants of alveolar macrophages from patients with interstitial lung diseases. Chest, 99, 674-680.

77. Takeuchi, M., Nagai, S., Tsutumi, T., Mio, T., Izumi, T. (1997) The number of interleukin 1 receptors in lung fibroblasts in patients with idiopathic pulmonary fibrosis. Respiration, 66, 236-241.

78. Steffen, M., Petersen, J., Oldigs, M., Karmeier, A., Magnussen, H., Thiele, H. G., Raedler, A. (1993) Increased secretion of tumor necrosis factor-alpha, interleukin-1-beta, and interleukin6 by alveolar macrophages from patients with sarcoidosis. J. Allergy Clin. Immunol., 91, 939-49.

79. Gogos, C. A., Drosou, E., Bassaris, H. P., Skoutelis, A. (2000) Pro- versus anti-inflammatory cytokine profile in patients with severe sepsis: a marker for prognosis and future therapeutic options. J. Infect. Dis., 181, 176-80.

80. Sutton, E. T., Norman, J. G., Newton, C. A., Hellerman, G. R., Richards, I. S. (1997) Endothelial structural integrity is maintained during endotoxic shock in an interleukin-1 type I receptor knockout mouse. Shock, 7, 105-10.

81. Koo, D. J., Chaundry, I. H., Wang, P. (1999) Kupffer cells are responsible for producing inflammatory cytokines and hepatocellular dysfunction during early sepsis. J. Surg. Res., 83, 151-7. 
82. Liu, X. H., Kwon, D., Schielke, G. P., Yang, G. Y., Silverstein, F. S., Barks, J. D. E. (1999) Mice deficient in interleukin-1 converting enzyme are resistant to neonatal hypoxic-ischemic brain damage. J. Cereb. Blood Flow Metab., 19, 1099-1108.

83. Hagberg, H., Gilland, E., Bona, E., Hanson, L. A., Hahn-Zoric, M., Blennow, M. et al. (1996): Enhanced expression of interleukin (IL-)-1 and messenger RNA and bioactive protein after hypoxiaischemia in neonatal rats. Pediatr. Res., 40, 603-609.

84. Furlan, R., Martino, G., Galbiati, F., Poliani, P. L., Smiroldo, S., Bergami, A., Desina, G. et al. (1999) Caspase-1 regulates the inflammatory process leading to autoimmune demyelination. J. Immunol., 163, 2403-2409.

85. Bidwell, J., Keen, L., Gallagher, G., Kimberly, R., Huizinga, T., McDermott, M. F., Oksenberg, J. et al. (1999) Cytokine gene polymorphism in human disease: on-line databases. Genes Immunity, 1, 3-19.

86. Bailly, S., di Giovine, F. S., Blakemore, A. I. F., Duff, G. W. (1993) Genetic polymorphism of human interleukin-1 $\alpha$. Eur. J. Immunol., 23, 1240-1245.

87. Pociot, F., Molvig, J., Wogensen, L., Worsaae, H., Nerup, J. (1992) A Taq polymorphism in the human interleukin-1 $\beta$ (IL$1 \beta)$ gene correlates with IL-1 $\beta$ secretion in vitro. Eur. J. Clin. Invest., 22, 396-402.

88. Santtila, S., Savinainen, K., Hurme, M. (1998) Presence of the IL-1RA allele 2 (IL-1RN*2) is associated with enhanced IL-1 $\beta$ production in vitro. Scand. J. Immunol., 47, 195-198.

89. Danis, V. A., Milington, M., Hyland, V. J., Grennan, D. (1995) Cytokine production by normal human monocytes: inter-subject variation and relationship to an IL-1 receptor antagonist (IL1Ra) gene polymorphism. Clin. Exp. Immunol., 99, 303-310.

90. Tountas, N. A., Casini-Raggi, V., Yang, H., di Giovine, F. S., Vecchi, M., Kam, L. et al. (1999) Functional and ethnic association of allele 2 of the interleukin- 1 receptor antagonist gene in ulcerative colitis. Gastroenterology, 117, 806-813.

91. Hurme, M., Santtila, S. (1998) IL-1 receptor antagonist (IL$1 \mathrm{Ra}$ ) plasma levels are co-ordinately regulated by both IL-1Ra and IL-1 $\beta$ genes. Eur. J. Immunol., 28, 2598-2602.

92. Hurme, M., Lahdenpohja, N., Santtila, S. (1998) Gene polymorphisms of interleukins 1 and 10 in infectious and autoimmune diseases. Ann. Med., 30, 469-473.

93. Mansfield, J. C., Holden, H., Tarlow, J. K., di Giovine, F. S., McDowell, T. L., Wilson, A. G. et al. (1994) Novel genetic asssociation between ulcerative colitis and the anti-inflammatory cytokine interleukin-1 receptor antagonist. Gastroenterology, 106, 637-642.

94. Heresbach, D., Alizadeh, M., Dabadie, A., Le Berre, N., Colombel, J. F., et al. (1997) Significance of interleukin-1 $\beta$ and interleukin-1 receptor antagonist genetic polymorphism in inflammatory bowel disease. Am. J. Gastroenterol., 92, 1164-1169.

95. Hacker, U. T., Gomolka, M., Keller, E., Eigler, A., Folwaczny, C., Fricke, H. et al. (1997) Lack of association between an interleukin1 receptor antagonist gene polymorphism and ulcerative colitis. Gut, 40, 623-627.

96. Bioque, G., Crusius, J. B., Koutroubakis, I., Bouma, G., Kostense, P. J., Meuwissen, S. G., Pena, A. S. (1995) Allelic polymorphism in IL-1 beta and IL-1 receptor antagonist (IL-1Ra) genes in inflammatory bowel disease. Clin. Exp. Immunol., 102, 379-383.

97. Sitara, D., Olomolaiye, O., Wood, N., Keen, L., Morse, H., Elson, C. et al. (1999) Identification of novel single nucleotide polymorphisms in intron $1 \mathrm{~B}$ and exon $1 \mathrm{C}$ of the human interleukin-1 receptor type I (IL-1RI) gene. Genes Immunity, 1, 161-163.

98. Sitara, D., Wood, N., Morse, H., Keen, L., Bidwell, J. (2000) A Bsr BI polymorphism in exon $1 \mathrm{C}$ of the human interleukin-1 receptor type I (IL-1RI) gene. Genes Immunity, 1, 234-235.

99. di Giovine, F. S., Takhsh, E., Blakemore, A. I. F., Duff, G. W. (1992) Single base polymorphism at -511 in the human interleukin-1 $\beta$ gene (IL1 $\beta$ ). Hum. Mol. Genet., 1, 450.

100. Guasch, J. F., Bertina, R. M., Reitsma, P. H.(1996) Five novel intragenic dimorphisms in the human interleukin-1 genes combine to high informativity. Cytokine, 8, 598-602.

101. Tarlow, J. K., Blakemore, A. I. F., Lennard, A. et al. (1993) Polymorphism in human IL-1 receptor antagonist gene intron 2 is caused by variable numbers of an $86-b p$ tandem repeat. Hum. Genet., 91, 403-4.
102. Tarlow, J. K., Clay, F. E., Cork, M. J., Blakemore, A. I. F., McDonagh, A. J. G., Messenger, A. G., Duff, G. W. (1994) Severity of alopecia areata is associated with a polymorphism in the interleukin-1 receptor antagonist gene. J. Invest. Dermatol., 103, 387-390.

103. Cookson, S., Constantin, P. K., Clare, M., Underhill, J. A., Bernal, W., Czaja, A. J., Donaldson, P. T. (1999) Frequency and nature of cytokine gene polymorphism in type 1 autoimmune hepatitis. Hepatology, 30, 851-856.

104. Heward, J., Allahabadia, A., Gordon, C., Sheppard, M. C., Barnett, A. H., Franklyn, J. A., Gough, S. C. L. (1999) The interleukin-1 receptor antagonist gene shows no allelic association with three autoimmune diseases. Thyroid, 9, 627-8.

105. Hurme, M., Helminen, M. (1998) Resistance to human cytomegalovirus infection may be influenced by genetic polymorphisms of the tumour necrosis factor-alpha and interleukin-1 receptor antagonist genes. Scand. J. Infect. Dis., 30, 447-449.

106. Louis, E., Satsangi, J., Roussomoustakaki, M., Parkes, M., Fanning, G., Welsh, K. et al. (1996) Cytokine gene polymorphisms in inflammatory bowel disease. Gut, 39, 705-710.

107. Petřek, M., Drábek, J., Kolek, V., Puscinska, E. (1997) IL-1RA polymorphism in interstitial lung disease. Immunol. Letters, 56, 411.

108. Loughrey, B. V., Maxwell, A. P., Fogarty, D. G., Middleton, D., Harron, J. C., Patterson, C. C. et al. (1998) An interleukin-1B allele, which correlates with high secretor phenotype, is associated with diabetic nephropathy. Cytokine, 10, 984-988.

109. Tarnow, L., Pociot, F., Hansen, P. M., Rossing, P., Flemming, S. N., Hansen, B. V. et al. (1997) Polymorphisms in the interleukin-1 gene cluster do not contibute to the genetic susceptibility of diabetic nephropathy in Caucasian patients with IDDM. Diabetes, 46, 1075-1941.

110. Blakemore, A. I., Cox, A., Gonzales, A. M., Maskil, J. K., Hughes, M. E., Wilson, R. M. et al. (1996) Interleukin-1 receptor antagonist allele (IL-1RN*2) associated with nephropathy in diabetes mellitus. Hum. Genet., 97, 369-74.

111. Keen, R. W., Woodford-Richens, K. L., Lanchbury, J. S., Spector, T. D. (1998) Allelic variation at the interleukin-1 receptor antagonist gene is associated with early postmenopausal bone loss at the spine. Bone, 23, 367-71.

112. McDowell, T. L., Symons, J. A., Ploski, R., Forre, O., Duff, G. W. (1995) A genetic association between juvenile rheumatoid arthritis and a novel interleukin- $1 \alpha$ polymorphism. Arthritis Rheum., 38, 221-8.

113. Donn, R. P., Farhan, A. J., Barrett, J. H., Thomson, W., Worthington, J., Ollier, W. E. (1999) Absence of association between interleukin 1 alpha and oligoarticular juvenile chronic arthritis in UK patients. Rheumatology (Oxford), 38, 171-5.

114. Tarlow, J. K., Cork, M. J., Clay, F. E., Schmidt-Egenolf, M., Crane, A. M., Stierle, C. et al. (1997) Association between interleukin-1 receptor antagonist (IL-1Ra) gene polymorphism and early and late-onset psoriasis. Brit. J. Dermatol., 136, 147-148.

115. Hurme, M., Helminen, M. (1998) Polymorphism of the IL-1 gene complex in Epstein-Barr virus seronegative and seropositive adult blood donors. Scand. J. Immunol., 48, 219-222.

116. Mühlberg, T., Kirchberg, M., Spitzweg, C., Herrman, F., Heberling, H.J., Heufelder, A. E. (1998) Lack of association of Graves disease with the A2 allele of the interleukin-1 receptor antagonist gene in a white European population. Eur. J. Endocrinol., 138, 686-690.

117. Liu, Z. H., Cheng, Z. H., Yu, Y. S., Tang, Z., Li, L. S. (1997) Interleukin-1 receptor antagonist allele: Is it a genetic link between Henoch-Schonlein nephritis and IgA nephropathy? Kidney Int., 51, 1938-1942.

118. Bergholdt, R., Karlson, A. E., Johannesen, J., Hansen, P. M., Dinarello, C. A., Nerup, J. et al. (1995) Characterization of polymorphisms of an interleukin 1 receptor type 1 gene (IL1RI) promotor region $(\mathrm{P} 2)$ and their relation to insulin-dependent diabetes mellitus (IDDM). Cytokine, 7, 727-33.

119. Clay, F. E., Cork, M. J., Tarlow, J. K., Blakemore, A. I. F., Harrington, C. I. et al. (1994) Interleukin-1 receptor antagonist gene polymorphism association with lichen sclerosus. Hum. Genet., 94, 407-410. 
120. Crusius, J. B. A., Pena, A. S., van Oosten, B. W., Bioque, G., Garcia, A., Dijkastra, C. D., Polman, C. H. (1995) Interleukin-1 receptor antagonist gene polymorphism and multiple sclerosis. Lancet, 346, 979-980.

121. Sciacca, F. L., Ferri, C., Vandenbroeck, K., Veglia, F., Gobbi, C., Martinelli, F. et al. (1999) Relevance of interleukin-1 receptor antagonist intron 2 polymorphism in Italian MS patients. Neurology, 52, 1896-1898.

122. Schrijver, H. M., Crusius, J. B. A., Uithaag, B. M. J., Gonzalez, M. A. G., Kostense, P. J., Polman, C. H. et al. (1999) Association of interleukin-1 $\beta$ and interleukin-1 receptor antagonist genes with disease severity in MS. Neurology, 52, 595-599.

123. Huang, D., Pirskanen, R., Hjelmstrom, P., Lefvert, A. K. (1998) Polymorphisms in IL-1beta and IL-1 receptor antagonist genes are associated with myasthenia gravis. J. Neuroimmunol., 81, 76-81.

124. Gore, E. A., Sanders, J. J., Pandey, J. P., Palesch, Y., Galbraith, G. M. (1998) Interleukin-1 beta +3953 allele 2: association with disease status in adult periodontitis. J. Clin. Periodont., 25, 781-5.

125. Kornman, K. S., Crane, A., Wang, H. Y., di Giovine, F. S., Newman, M. G., Pirk, F. W. et al. (1997) The interleukin-1 genotype as a severity factor in adult periodontal disease. J. Clin. Periodont., 24, 72-7.

126. Perrier, S., Coussediere, C., Dubost, J. J., Albuisson, E., Sauvezie, B. (1998) IL-1 receptor antagonist (IL-1RA) gene polymorphism in Sjögren's syndrome and rheumatoid arthritis. Clin. Immunol. Immunopathol., 87, 309-313.

127. Petřek, M., Laurincová, B., Mičeková, D., Bošák, V., Drábek, J., Weigl, E. (2000) IL-1 receptor antagonist gene polymorphism in primary Sjögren s syndrome. Rheumatologia, 14, 96.

128. Jouvenne, P., Chaudhary, A., Buchs, N., di Giovine, F. S., Duff, G. W., Miossec, P. (1999) Possible genetic association between interleukin- $1 \alpha$ gene polymorphism and the severity of chronic polyarthritis. Eur. Cytokine Netw., 10, 33-6.

129. Langabeer, S. E., Linch, D. C. (1998) IL-1 receptor antagonist gene polymorphism in patients with secondary myeloid leukaemia. Cytokines Cell Mol. Ther., 4, 7-9.
130. Fang, X. M., Schroder, S., Hoeft, A., Stuber, F. (1999) Comparison of two polymorphisms of the interleukin-1 gene family: Interleukin-1 receptor antagonist polymorphism contributes to susceptibility to severe sepsis. Crit. Care Med., 27, 1330-1334.

131. Laurent, C., Thibaut, F., Ravassard, P., Campion, D., Samolyk, D., Lafargue, C. et al. (1997) Detection of two new polymorphic sites in the human interleukin-1 beta gene: lack of association with schizophrenia in a French population. Psychiatr. Genet., 7, $103-5$.

132. Tatsumi, M., Sasaki, T., Sakai, T., Kamijima, K., Fukuda, R., Kunugi, H. et al. (1997) Genes for interleukin-2 receptor $\beta$ chain, interleukin-1 $\beta$, and schizophrenia: No evidence for the association or linkage. Am. J. Med. Genet., 74, 338-341.

133. Katila, H., Hanninen, K., Hurme, M. (1999) Polymorphisms of the interleukin-1 gene complex in schizophrenia. Mol. Psychiatry, $4,179-81$.

134. Tjerstrom, F., Hellmer, G., Nived, O., Truedsson, L., Sturfelt, G. (1999) Synergetic affect between interleukin-1 receptor antagonist allele (IL1RN*2) and MHC class II (DR17,DQ2) in determining susceptibility to systemic lupus erythematosus. Lupus, 8 , 103-8.

135. Bellamy, R., Ruwende, C., Corrah, T., McAdam, K. P., Whittle, H. C., Hill, A. V. (1998) Assessment of the interleukin 1 gene cluster and other candidate gene polymorphisms in host susceptibility to tuberculosis. Tuber. Lung Dis., 79, 83-9.

136. Hacker, U. T., Bidlingmeier, C., Gomolka, M., Keller, E., Eigler, A., Hartmann, G. et al. (1998) Inflammatory bowel disease: no association between allele combinations of the interleukin (IL) $1 \beta$ and IL-1 receptor antagonist gene polymorphism. Eur. J. Clin. Invest., 28, 214-219.

137. Nemetz, A., Nosti-Escanilla, M. P., Molnar, T., Kope, A., Kovacs, A., Feher, J. et al. (1999) IL1B gene polymorphisms influence the course and severity of inflammatory bowel disease. Immunogenetics, 49, 527-531.

138. Bouma, G., Crusius, J. B. A., Garcia-Gonzalez, M. A., Meijer, B. U. G. A., Hellemans, H. P. R., Hakvoort, R. J. et al. (1999) Genetic markers in clinically well defined patients with ulcerative colitis. Clin. Exp. Immunol., 115, 294-300. 